Controlled Chaos: Modeling Interdisciplinary Practice for Architecture and Engineering Students in a Real World Community Engaged Design Project.

Dr. Sinead MacNamara, Syracuse University Mr. Larry D Bowne II, Syracuse University 


\section{Controlled Chaos: Modeling Interdisciplinary Practice for Architecture and Engineering Students in a Real World Community Engaged Design Project.}

This paper describes, analyzes and assesses "The Berg", a design project undertaken by engineering and architecture students at Syracuse University in collaboration with the city of Syracuse. The students created designs for the conversion and expansion of a defunct Field House into a recreational facility and community center suitable an urban park in an impoverished near west side neighborhood. The authors, a structural engineer and licensed architect who served as advisors on the, assert that community-service design has the potential to ignite debate about design both outside and inside the professions. Who is entitled to good design? Do underserved constituencies, such as physically disabled children and lower income citizens, need good design? Does design for the socially and economically challenged need merely to meet minimum legal standards? What does design for such non-profit clienteles look like? What role do the values of so-called high architecture play in such community-engagement designs?

The Berg was realized in two courses: a comprehensive design studio for fourth year architecture students and a professional elective taken by mostly engineering students and a small number of architecture students. In consultation with multiple community and institutional stakeholders, the project afforded an opportunity for students and faculty alike to consider the issues outlined above and present their own responses. The multidimensional collaborations and design iterations represented an opportunity for the students to model modes of contemporary practice in engineering and architecture. For the architecture students it was a first experience in having to request, manage and appropriately integrate outside technical knowledge into their design process, for the engineering students it was their first exposure to the design process and the multifaceted way their highly specific skills are deployed in a real world process. The teaching, evaluation and assessment of the courses represent an opportunity for educators to think about the role of service learning in architecture and engineering education. The Berg compelled students to integrate technology and structure in the design process, required structural engineers to and as such can be seen as experiments in advancing design pedagogy.

\section{Background}

Design build, community service and the combination of the two are long-established modes of pedagogy and design research in schools of architecture. Among the most significant programs that have tested and refined methodologies are Studio 804 at University of Kansas ${ }^{1}$, Urban Build at Tulane University ${ }^{2}$, Rural Studio at Auburn University, ${ }^{3}$ and the Jim Vlock First Year Building Project at the Yale School of Architecture. ${ }^{4}$

Pedagogical advantages ascribed to design build and community engaged design by educators include: professional preparedness; exposure to alternate modes of practice; exposure to the realities of construction tolerances and accuracies; synthesis of knowledge learned in required courses $;{ }^{5}$ more refined knowledge of the materials and tools of design. ${ }^{6}$ Iwamoto and Scott argue that courses where students realize their

designs in built form are a unique opportunities to test "pedagogies of making."7 Writing specifically about community service design build projects, Francis asserts that such 
projects can be of significant value to architecture education, providing as they do an opportunity to expose students to the "social and psychosocial aspects of design" and "contrasting theories of aesthetics.",

On the negative side, Foote laments the time constraints of typical design build project that often demand a linear design then build process that can be prematurely deterministic. ${ }^{9}$ Erdman et al argue that much that has been written about design build "resists theorization" and too often presents the value of such programs as self evident or overly centered on either student empowerment or the social utility of the product. ${ }^{10}$ However, Corser and Gore note that in the years since the Erdman study, increasing emphasis on "action in the built environment in service of both education and community enrichment" has enriched the educational experience for design build and community engaged students. And Hinson writing about recent developments including those at Auburn University, similarly notes that the move towards "research-driven design-build studio offers the faculty and students involved the opportunity to expand their goals beyond student learning outcomes to addressing questions with impact much broader than the scale of the single building and with significance beyond the single client." 11

Research in the area of technical education for architecture students bolsters more qualitative and anecdotal evidence that there are pedagogical advantages inherent in design build and community Engaged design projects for real projects. Although architecture students do take technical courses there is good evidence to suggest that students do not absorb this knowledge (or indeed many other types of knowledge) when it presented in lecture format without a design context. John Folan, professor at Carnegie Mellon asserts that

"[d]elivered outside the context of a design scenario, already abstract concepts of social, legal, economic, and contractual performance become entirely opaque, or even impenetrable for most students. As a result, the content remains entirely irrelevant in the academic setting and many students emerge into the profession without the capacity to evaluate priorities as they relate to performance."12

This observation is supported by education research across disciplines in higher education that demonstrates the value of "just in time" learning where students learn complex tools and skills (a specific math concept for example) best when they have immediate need of that tool to achieve some other immediate work goal. ${ }^{13}$ 


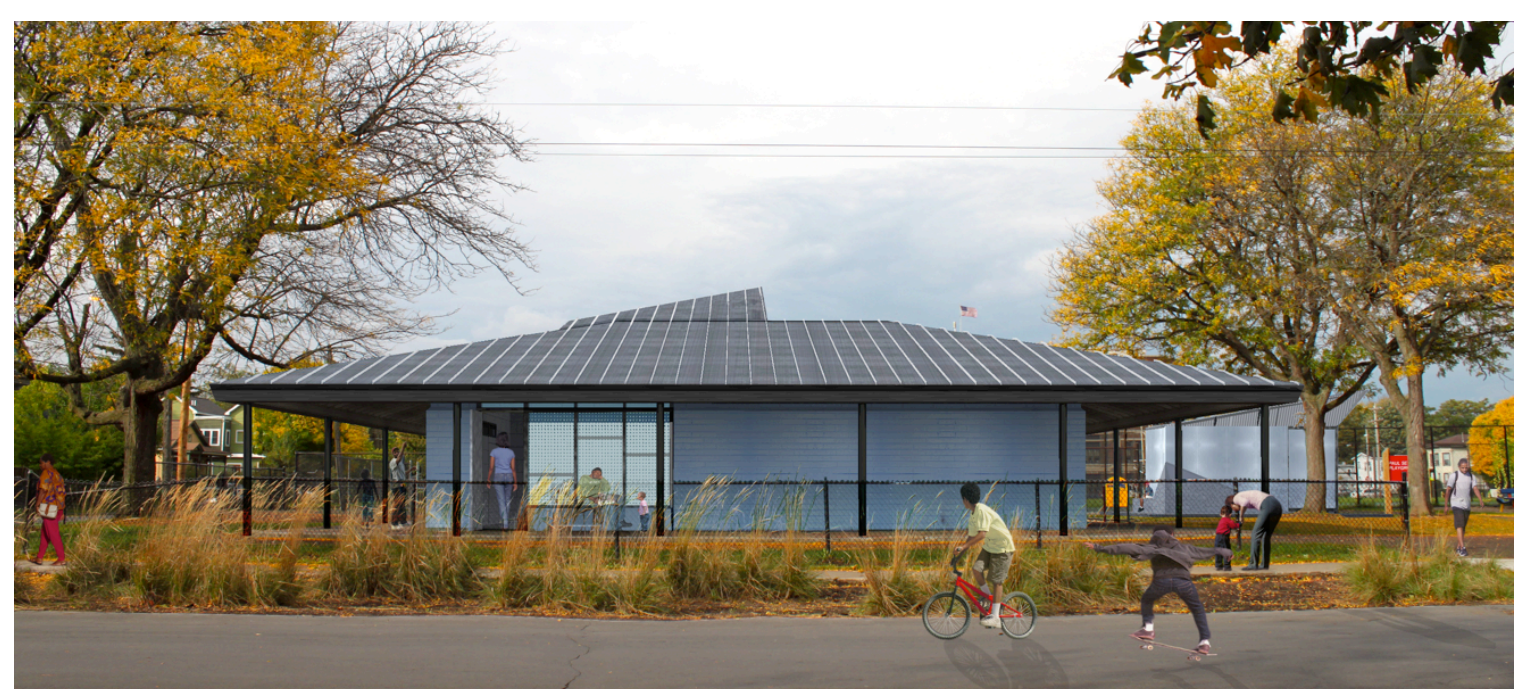

Figure 1: Rendering of proposed renovations to the Field House at Skiddy Park.

Following a successful community engaged and design build project with students from AIAS Freedom By Design that was completed as extra curricular work, the authors were in search of a project to bring community engaged design work with real world projects under a curricular umbrella. A number of potential projects, some with a design build component, each with varying groups of community stakeholders were considered. The most promising of these offerings was a proposal from Marc Norman, then-director of UPSATE, SyracuseUniversity's center for real estate, research and design, who had secured funding for improvements to a public park in the Near Westside of Syracuse, one of the city's most impoverished but also culturally rich neighborhoods.

The authors working closely with Marc Norman and a pair of Imagining America research fellows, began planning courses that could advance a new collaboration in the public realm, a first for Syracuse architecture and engineering students working within the curricular framework of the design studio and professional elective courses.

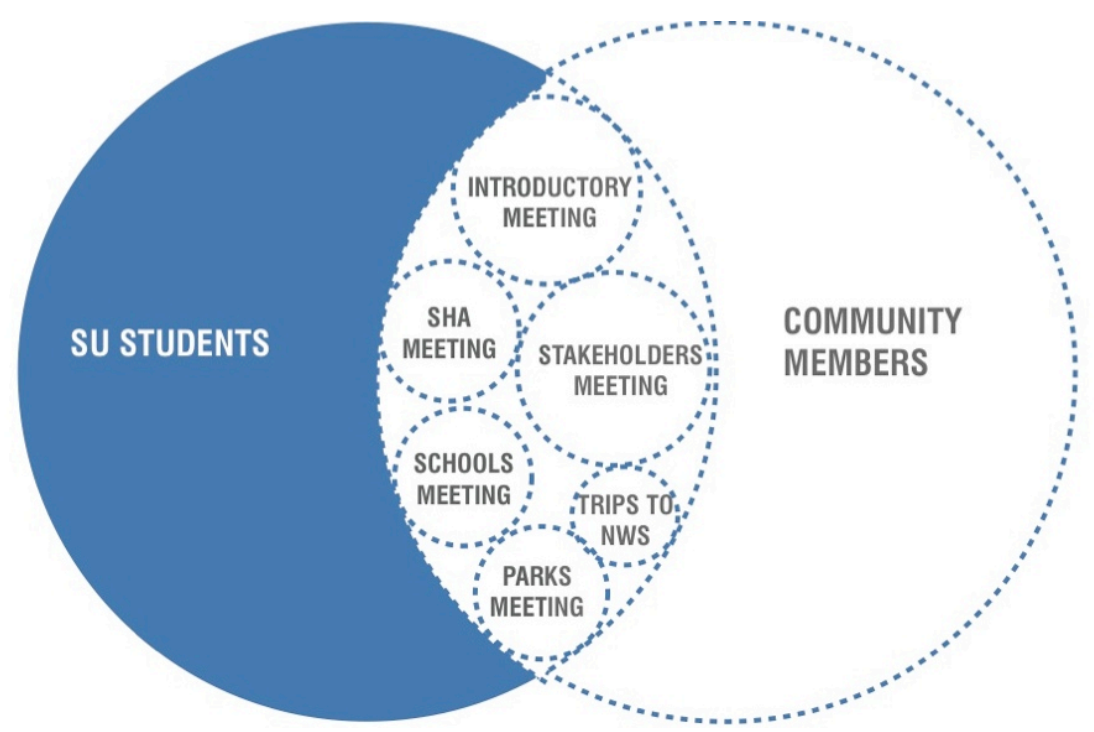

Figure 2: Diagram, showing student interaction with local stakeholders and neighborhood representatives, including the Syracuse Housing Authority, schools and the Parks Department. 


\section{The Client}

The client group for The Berg was somewhat nebulous. Principal funding had come from UPSATE, a Syracuse School of Architecture affiliate, but the City of Syracuse would need to substantively match those funds if the project were going to be implemented as the students had set out to plan. Students also worked with Imagining America Engagement Fellows, Near Westside Initiative a town/gown organization aimed at revitalizing the impoverished near west side of the city of Syracuse. While the nominal client was the City of Syracuse Department of Parks, Recreation and Youth Services, the actual holder of title to the land on which the park sits was the Syracuse Housing Authority; further, the local school district (which ran nearby schools for elementary, middle-school and high-school children) had a contractual right to use the Field House and adjacent play areas. In addition to the these formal relations, students had to treat the larger network of local residents, businesses and institutions as part of their user group(s), if not their actual client(s).

\section{The Berg: Coursework and Curriculum}

The authors set up two related courses: a six-unit section of the Comprehensive Design Studio, open to fourth-year undergraduates in SU's professional program, and a threecredit hour professional elective, open to students in architecture and engineering. Students enrolled in these two courses were joined by a student in Industrial Design from the school of Visual and Performing Arts and the aforementioned pair of Imagining America Engagement Fellow. Together, the group branded itself as Park Studio.

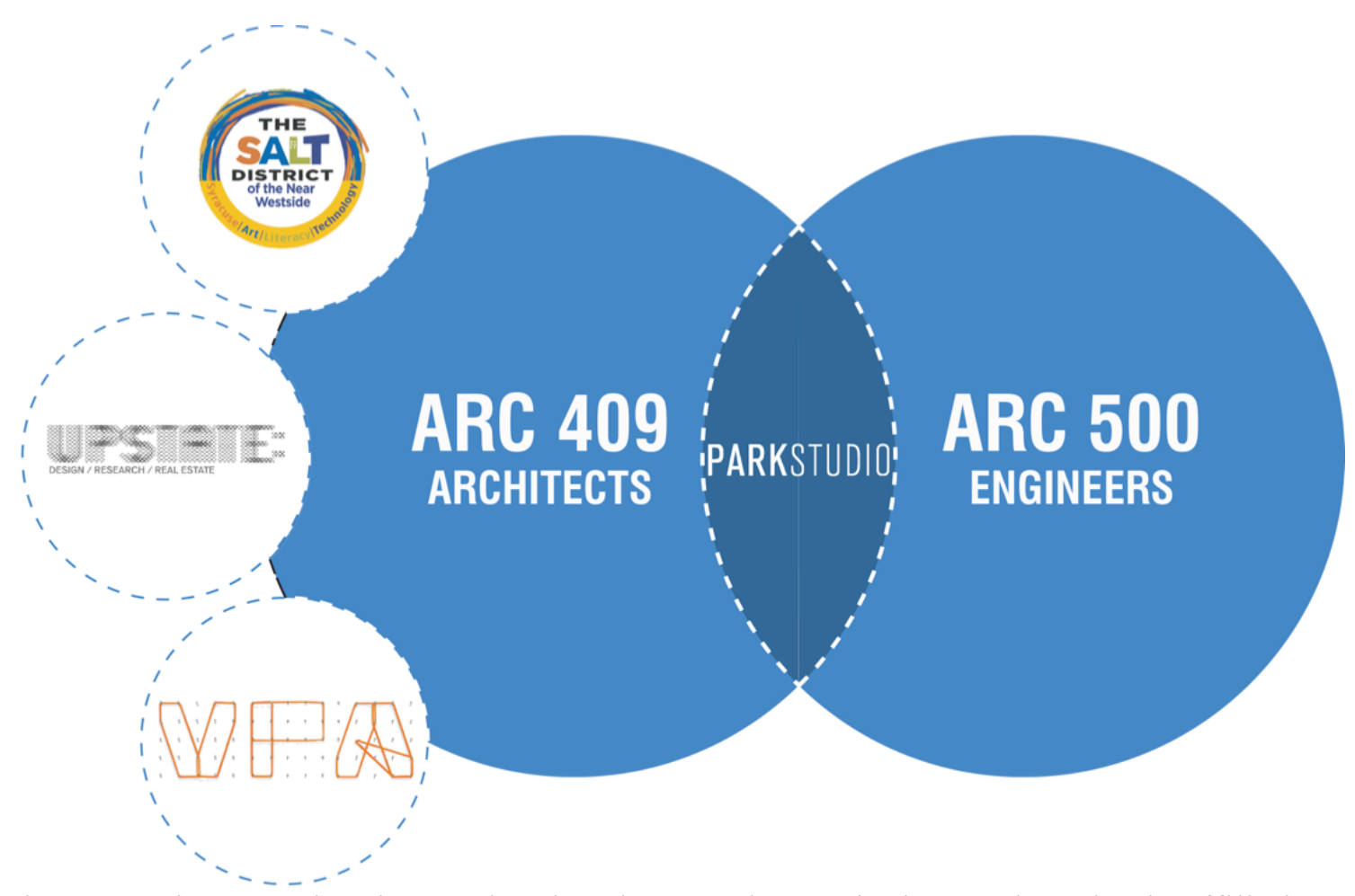

Figure 3: Diagram, showing student involvement by curriculum and academic affiliation. 
We chose to craft a special section of Comp Studio, heeding the specific parameters of prevailing conditions for accreditation, which specifically sites the need for students to demonstrate the:

"[a]bility to produce a comprehensive architectural project that demonstrates each student's capacity to make design decisions across scales while integrating the following SPC (Student Performance Criteria): A.2. Design Thinking Skills, A.4. Technical Documentation, A.5. Investigative Skills, A.8. Ordering Systems, A.9. Historical Traditions and Global Culture, B.2. Accessibility, B.3. Sustainability, B.4. Site Design, B.5. Life Safety, B.8. Environmental Systems, B.9. Structural Systems. ${ }^{14}$

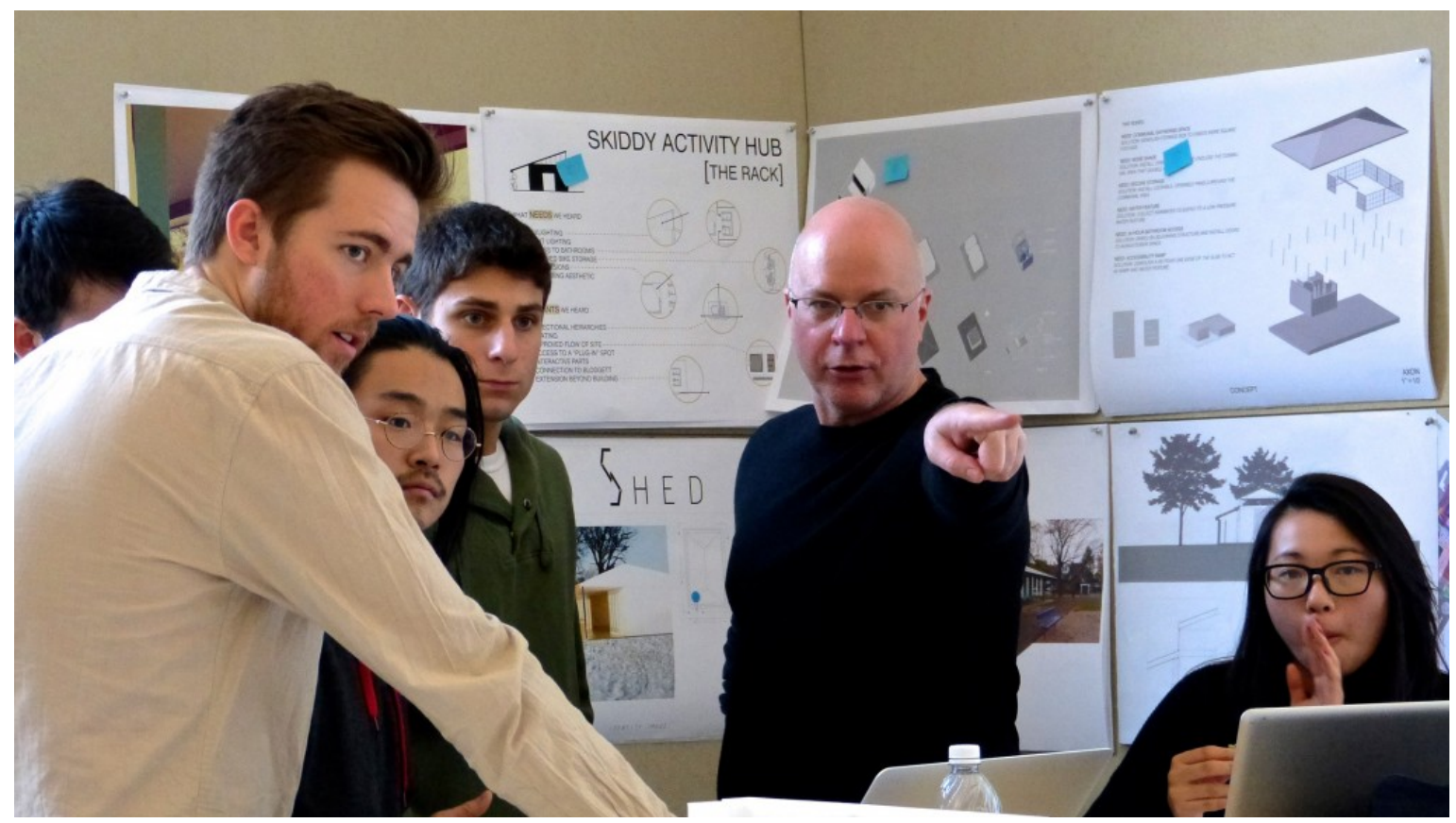

Figure 4: Comprehensive Design Studio collaborative session.

In addition, the new 2014 Conditions have added a Realm D Requirement:

D.1 Integrative Design: Ability to produce an architectural solution that demonstrates the ability to make design decisions about a single project while demonstrating broad integration and consideration of environmental stewardship, technical documentation, accessibility, site conditions, life safety, environmental systems, structural systems, and building envelope systems and assemblies. ${ }^{15}$

While the facts of working with a real client on a genuine site, on a project that the Parks Department was committed to executing, afforded the opportunity to address most of the NAAB requirements, the small scale of the existing Field House did not afford students the opportunity to design large-span structures, complicated building assemblies, or environmental controls systems.

These potential deficiencies were addressed in two ways: first, the studio coordinator established a series of Practice Model Talks, in which faculty teaching Comp Studio 
would situate their studio offering amidst discourses and trajectories prevailing within the larger discipline. Specifically, this activity called on faculty to "discuss a set of exemplary buildings that align with an individual studio's exploration, outline certain exciting practices, explore adjacent disciplinary topics or describe the reasons for assigning a particular studio's project." These talks, which happened over the course of the term, became an open forum for learning and discussion, in which divergent sectional approaches and their attendant opportunities and limitations became publicly addressed, analyzed and assessed.

More significantly, the authors took the small size of the existing Field House (under $700 \mathrm{sf}$ ) as an opportunity to engage an immersive design of structure, cladding and thermal comfort at discrete scales. ARC 500 professional elective seminar, "CommunityEngaged Engineering Design (CEED)," simultaneously surveyed the existing facilities of Skiddy Park and studied other parks within the City of Syracuse so that the emerging design would be not just a one-off project but rather an exemplar for future renovations. At the scale of the site, students assessed water run-off and retention, accessibility for emergency vehicles and fire suppression, solar height gain, wind patterns, and the like. At the level of technical development, Park Studio collaboratively modeled the structural performance of various proposals, after which CEED students prepared a series of engineering reports (more on which below).

The team paid special attention to community outreach, with Comp Studio and CEED students creating special focus groups to interact with Parks, the Housing Authority, and local schools. Evening sessions one day a week were devoted to the exchange of facts, ideas, and aspirations.

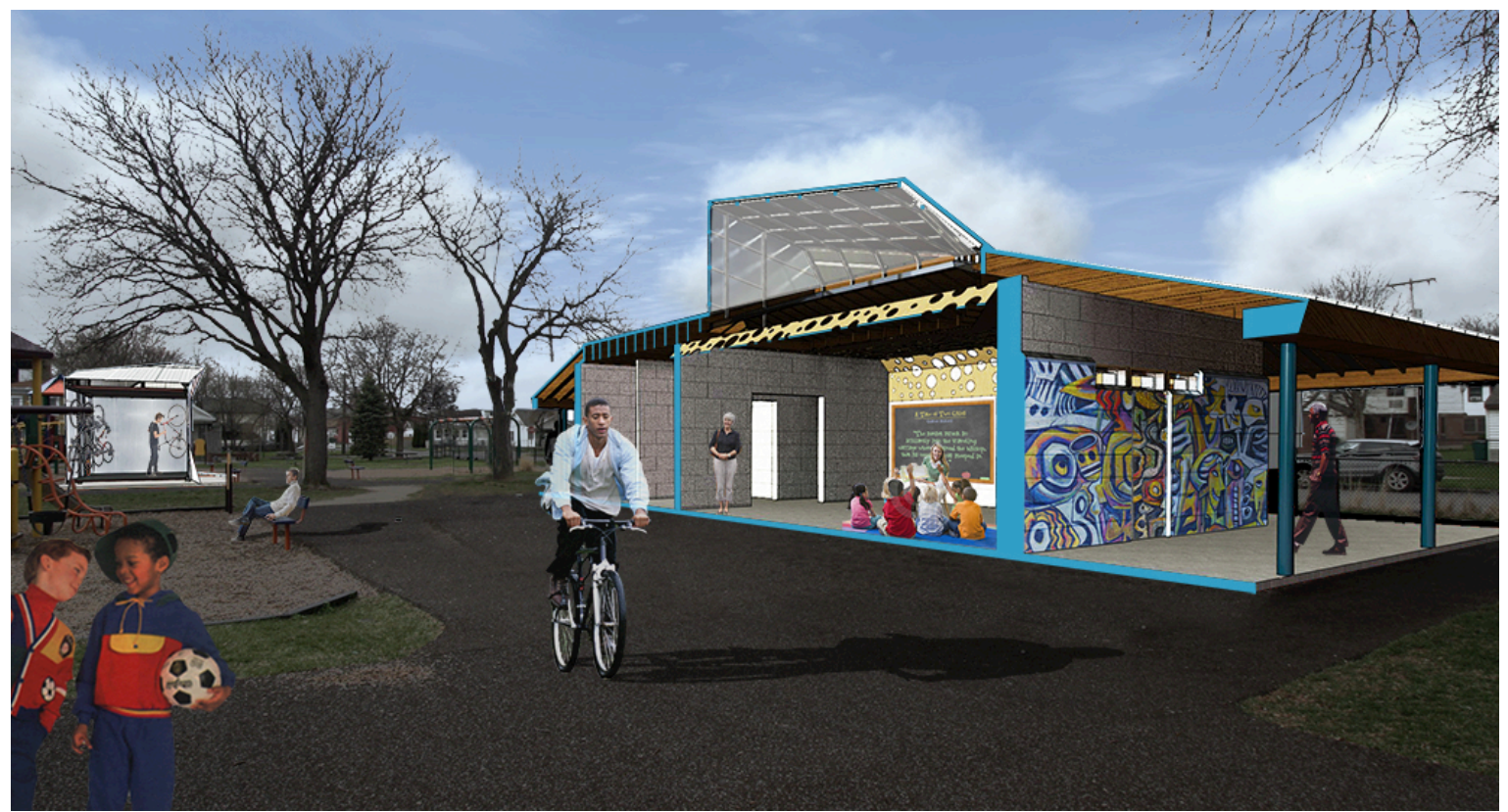

Figure 5: Foreground, a sectional perspective rendering of "The Berg," showing the new profile of the room, enhanced gathering space in the interior, and stronger connections to exterior play spaces 


\section{The Berg: Design Process}

From the outset, the team identified the opportunity to collaborate with the Parks Department so that whatever came of the Park Studio research would serve as a prototype for the enhancement and revitalization of other field houses, most of which were built in the middle of the $20^{\text {th }}$ Century, for $21^{\text {st }}$-Century uses and needs.

Some issues became paramount: most of the extant Field Houses had been constructed in an era when the functional requirements of organized teams sports (such as Little League) prevailed over multi-faceted, ad hoc and informal constituencies, who now comprise the majority of contemporary park users. Additionally, the Field Houses were designed and built without an emphasis on passive heating, cooling, ventilation and lighting, and as such their environmental performance and habitability were constrained. To help make buildings within city parks vital and contemporary, the design team emphasized environmental performance, transitional and transitory uses, and community concerns about accessibility, openness and security.

Working closely within the group and with external constituencies, Park Studio proposed The Berg, a paired set of design responses. First, the Field House itself would have handicapped accessible ramps and restroom; we would add new, wider doors and enhanced glazing; and we would open the roof to create a clerestory that would be provide day-lighting and serve as a beacon in the evening. Second, the students designed Little Berg, a flexible storage building and gathering space that would, at least in the short term, serve as a secure location for a highly popular community bicycling program that operates on weekends and afternoons in Skiddy Park and the Near Westside. Together, the renovated and new structure would create public spaces for gathering, performances and events.

In addition to the community outreach described above, architects in Comp Studio collaborated with their engineering colleagues in CEED. Typically, this collaboration involved architecture students learning to frame their issues and questions in terms that prevail in the engineering disciplines. More significantly, the architecture students needed to learn how to treat the engineers with the respect and deference commensurate with their allied, though discrete, expertise. Too often, the architecture students expected immediate calculations, estimations and analyses of their (often ill-considered) speculations, and the engineering students had to learn to politely, though professionally, establish appropriate professional boundaries. 


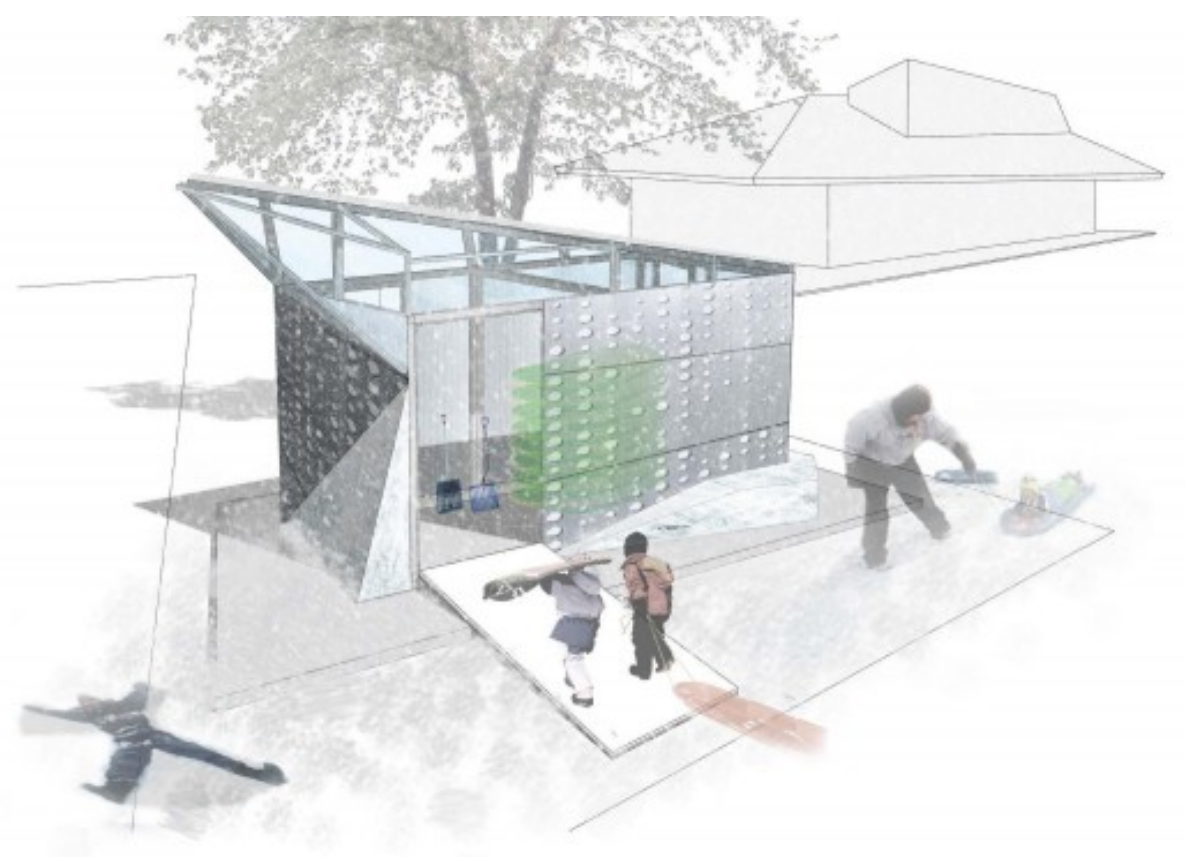

Figure 11: Foreground, a rendering of "Little Berg," a storage building for up to thirty bicycles that serve as the basis for a community cycling program; in the distance, the profile of the renovated Field House, The Berg.

Over the course of the term, students collaborated on wide range of deliverables intended to be provided to the Parks Department, a useful set of artifacts in describing their intentions, not only to each other but to their community constituents. Students produced contract documents, suitable for bidding, that included working drawing set for The Berg and Little Berg; a Project Manual, enumerating products and finishes; a series of related engineering reports, that describe the structural behavior of various schemes; and mockups of fabrication techniques and material assemblies.

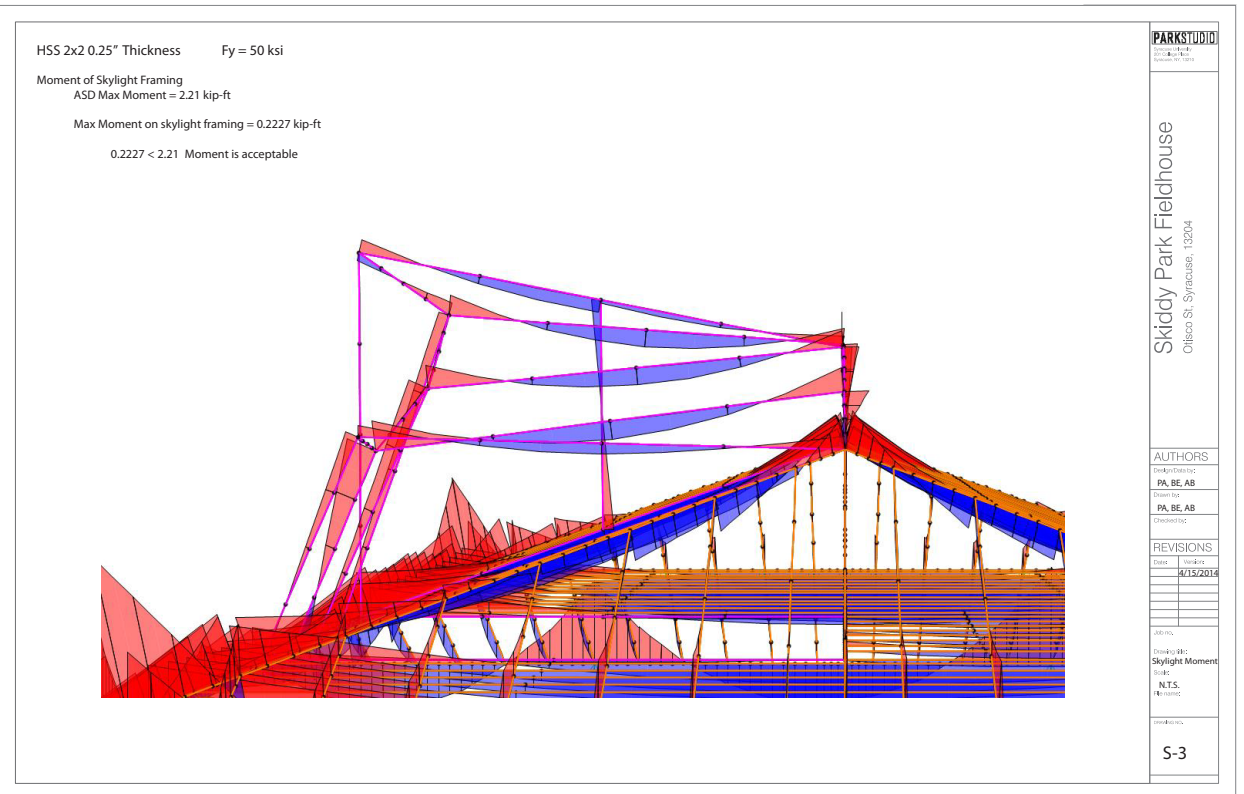

Figure 12: Excerpt, ARC 500 “Community-Engaged Engineering Design,” moment analysis of new skylight at The Berg. 


\section{The Berg: Prototyping and Fabrication}

The Berg project process closely approximated the constraints and opportunities of professional practice in the design disciplines. In its vital simulacrum of prevailing modes of architecture in the Design Build context, Park Studio relied on the production less of physical manifestations of proposed assemblies and more on the kinds of artifacts that architects typically produce in the provision of professional services.

For significant details, the students in ARC 409, worked closely with their collaborators in ARC 500 and the Department of Parks division of Skilled Trades (who would most likely be charged with the production, erection and installation of much of the specialty construction for both The Berg and The Little Berg). For several components, Park Studio built large-format tectonic models (typically at the scale of $3 / 4 "=1$ ' -0 "), half-fullsize mockups, and full-scale prototypes, with components shopped out to local metal shops as required (see Figure 13). Project teams focused on aspects of the project which demands the most careful coordination, including the new door and window openings in the Skiddy Park Field House; the new skylight and roof monitor on the same building; and the cladding systems intended for use on the bicycle storage building, which at one had to be secure, straightforward to fabricate, and easy to maintain.

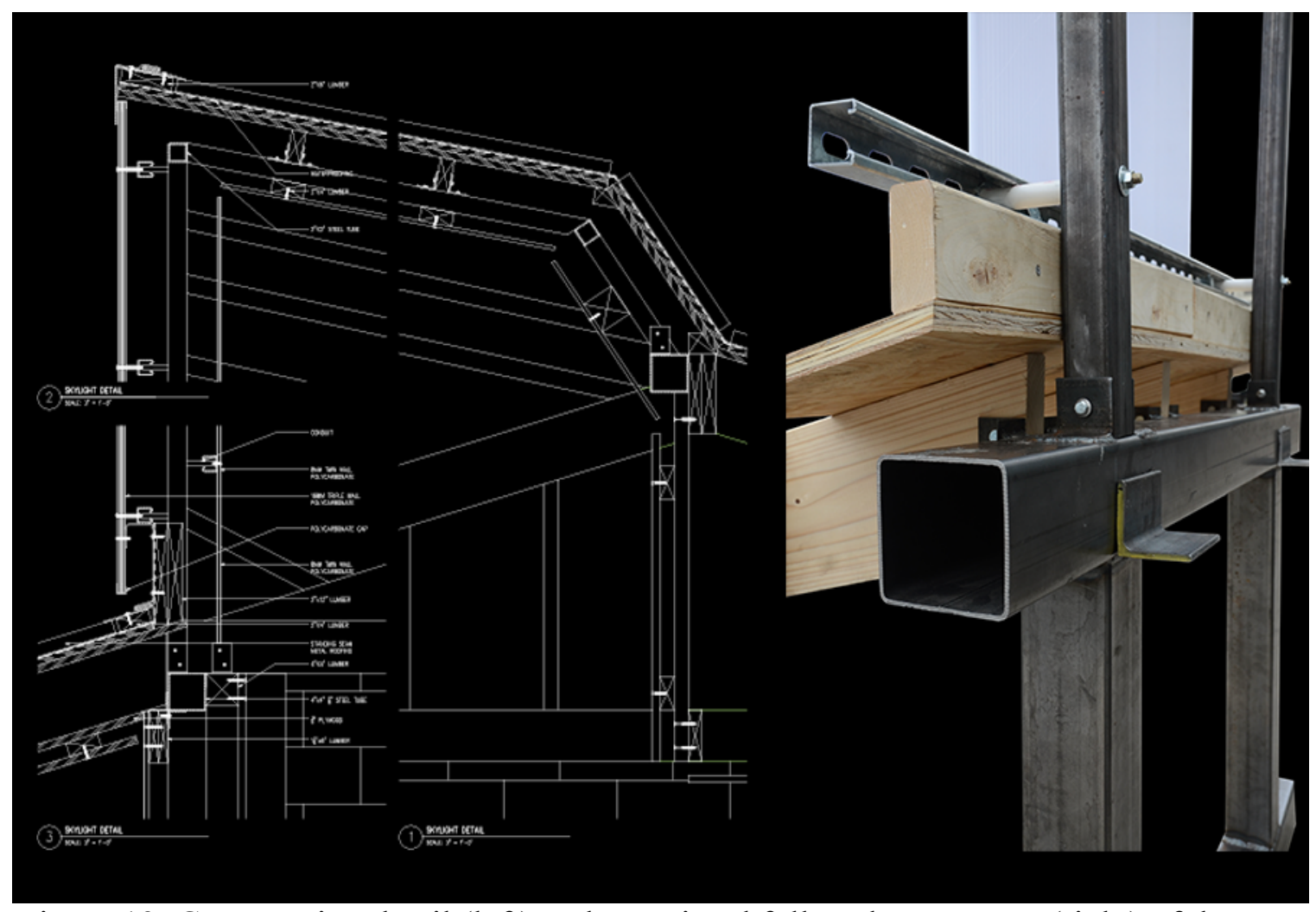

Figure 13: Construction detail (left) and associated full-scale prototype (right) of the new skylight at The Berg.

\section{The Berg: Financing and Budgeting}

Seed funding secured by Dean Robbins and former Chancellor Cantor, of $\$ 35,000$ was pledged to Park Studio. The City of Syracuse approved matching funds for the project in 
the summer of 2014. Subsequent to the student's submittal of the designs to the city, a local state senator has taken an interest in the project and a further $\$ 70,000$ in state funding has been secured. The project is scheduled to begin construction in 2015 .

\section{Curricular Implications}

The courses that the authors established for The Berg ultimately proved to have intersections with the existing academic course structure and frequently exceeded the confines of traditional curricula. In the sections that follow, we recount some of the particulars emerging from the courses, with frequent citations from the students' own evaluations of their involvement in the project.

\section{Technology}

Too often, students perceive disconnect between lectures in technical classes and the drawings they prepare for studio final reviews. Students may lack confidence in their capacity to correctly draft such systems, or they may have come to view the making of architecture as secondary to the conceiving of architecture. Different pedagogical cultures exist in different programs, of course, but we are all familiar with the trope that casts building technology and structures courses as "support" and design as somehow outside practical consideration.

In teaching our courses in Design Build and community engagement projects, the authors have aimed to circumvent that bias. Students enrolled in our courses have come to understand the value of technical expertise and the control they garnered over the creative design process when they possessed the knowledge and skills required to realize the design at full scale, in real time and in physical form, for a genuine client.

For students in the CEED seminar, which blended engineering and architecture, students focused on testing proposed designs with calculations and computer models, relying on genuine parameters such as the snow load allowed under New York State codes. In integrating the technical rigor of engineering disciplines with the open design process of an architecture class, students to replicated prevailing modes of technical interchange, in which students offered recommendations on the shape, number and various kinds of materials

For civil engineering student Stephanie Sanchez,

[i]t was an eye-opening experience to see how much we actually do know how to do. We got the chance to visually see and apply what we know and it makes so much more sense when you see it in front of you. Our professors emphasized that the lack of coordination is actually a huge issue in reality between architects and engineers, and we were able to see exactly that in our short time of working with the studio. Whenever I do enter the working field, I will already have in mind what it will be like or what to expect. ${ }^{16}$ 
Most students found an incredibly rewarding challenge in reconciling the discursive and iterative nature of the design studio with the more straightforward, directed expectations of engineering courses.

\section{Professional Practice}

More than any singular result Park Studio students learned the realities of working with a real client on a real site with a real budget. For Park Studio, that client was manifold and multifaceted. Glen Lewis of the Parks Department notes that neighborhood stakeholders "wanted to see a building that would be more open and could be used for special events, with better lighting, increasing the sense of safety, and more seating."

Julian Curry of Park Studio commented that

"[i]t's a different perspective when you know your work is going to affect people's lives. The most rewarding part was engaging with the community and seeing how design can make an impact."

At the same time, students needed to transcend the specific needs of Skiddy Park to meet the larger goals of the Parks Department, who wanted to incorporate environmental strategies and programmatic activities that would both bring the Field House into the $21^{\text {st }}$ Century and also serve as a template for future renovations which might take place across the citywide network of parks, playground and recreational areas.

Over the duration of the project, students had to learn professional-level skills that are nearly impossible to train within the normative context of the design studio, which posits that whatever will be built from the students' work will be realized at some other time in some other location by somebody else at some other scale. Or, more likely, it will not be realized by anyone, anywhere, ever.

Park Studio allowed students the luxury to master their skills at client presentations, contractual negotiations, zoning and code compliance, financing and funding, estimating and budgeting, scheduling and logistics. Since the project was structured and administered as a simulacrum of professional client / designer relations, students gained a range of experiences that would have been impossible in an alternative setting. 


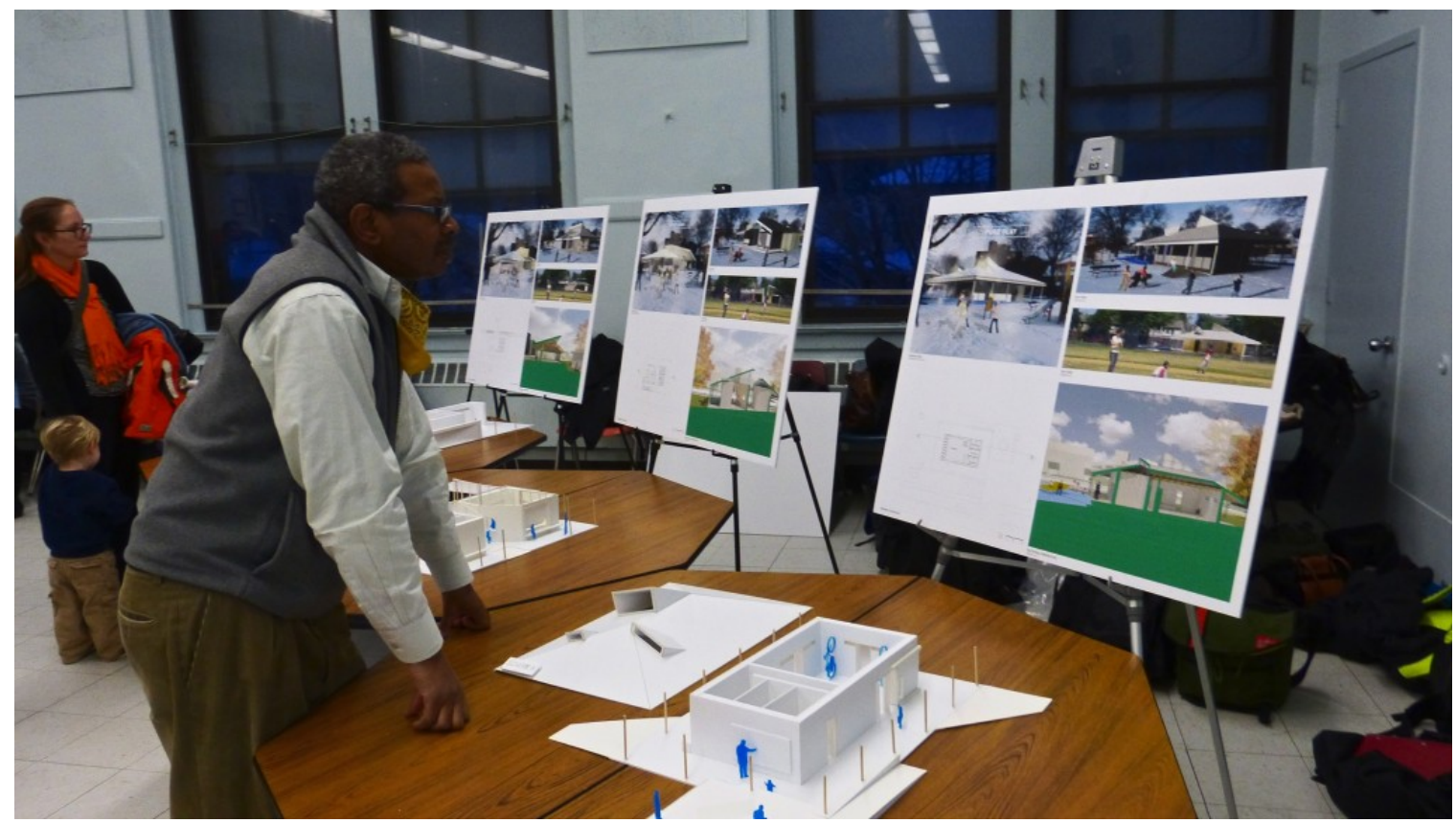

Figure 6: Glen Lewis, from the City of Syracuse Department of Parks, Recreation and Youth Programs, inspects schematic design presentations at a community meeting at Blodgett School.

\section{Conclusions and Future Work}

The projects described above represent a departure for the Syracuse University School of Architecture and have proved something of a risk for all concerned. However, the work has proven remarkably successful, providing momentum for additional courses in the realm of Design Build, community engagement, and Public Interest Design.

Park Studio students consistently approached their work as opportunities to contribute to the field of architecture and to the public understanding of the value of design as an agent of community enhancement. The quality of their design work has been extraordinary and their commitment to realizing their exact vision in physical form remarkable. From our first interaction with our students, they have aspired to question and challenge the prevailing modes of planning and administering socially engaged design; often in such contexts, good intentions suffice. Worse, the viability of a design - whether or not students have the skill or acumen to build something - can supersede and even overwhelm aesthetic or formal considerations. Instead, the students worked to craft each decision, relying on the decades long experience in the region of steelworkers, wood suppliers and other trades, and not merely deploying but extending their own skills learned in their courses and design studios. The aesthetic ambitions of the project are readily apparent in the work.

\footnotetext{
${ }^{1}$ Rockhill, Dan. "Studio 804." University of Kansas, n.d. Web. 15 Feb. 2014. <http://studio804.com>.

${ }^{2}$ Mouton, Byron. "URBANbuild." Tulane City Center>. Tulane School of Architecture, n.d. Web. 15 Feb. 2014.< http://www.tulanecitycenter.org/program s/urbanbuild $>$.
} 
${ }^{3}$ Citizen Architect: Samuel Mockbee and the Spirit of the Rural Studio. Film. Directed by Sam Wainright Douglas. Austin, TX: Big Beard Flims, 2010.

${ }^{4}$ Hopfner, Adam. "Yale School of Architecture." The Jim Vlock First Year Building Project. Yale School of Architecture, n.d. Web. 15 Feb. 2014. <http://architecture.yale.edu/student-life/vlock-building-project>.

${ }^{5}$ Ascher-Barnstone, Deborah. "Building Designs for Living: Studio 804 University of Kansas." Journal of Architectural Education 55.3 (2002): 186-193. Print.

${ }^{6}$ Boza, Luis Eduardo. "(Un)Intended Discoveries Crafting the Design Process.” Journal of Architectural Education 60.2 (2006): 4-7. Print.

${ }^{7}$ Iwamoto, Lisa, and Craig Scott. "Surface/Thickness Translated: Design-Build as Vehicle." Journal of Architectural Education 54.3 (2001): 185-190. Print.

${ }^{8}$ Francis, Mark, “Community Design” Journal of Architectural Education 37.1 (1983): 14-19. Print.

${ }^{9}$ Foote, Jonathan. "Design-Build :: Build-Design." Journal of Architectural Education 65.2 (2012): 52-58. Print.

${ }^{10}$ Erdman, Jori, Robert Weddle, Thomas Mical, Jeffery S. Poss, Kevin Hinders, Ken Mccown, and Chris Taylor. "Designing/Building/Learning." Journal of Architectural Education 55.3 (2002): 174-179. Print.

${ }^{11}$ Hinson, David. "Design as Research Learning from Doing in the Design-Build Studio." Journal of Architectural Education 61.1 (2007): 23-26. Print.

${ }^{12}$ Folan, John. "Exclusively Mutual." Performative Practices: Architecture and Engineering in the $21^{\text {st }}$ Century, edited by William Braham \& Kiel Moe. ACSA Teachers Conference. New York City, 2011.

${ }^{13}$ Simkins, Scott. Just-in-time teaching: across the disciplines, across the academy. Sterling, Va.: Stylus Pub. 2010. Print.

${ }^{14}$ Realm B, 2009 Conditions for Accreditation, The National Architectural Accrediting Board, Inc. Approved 7/10/09.

${ }^{15}$ Ibid.

${ }^{16}$ Haley, Kathleen. "Students Meld Creativity, Community Needs in Field House Redesign." Syracuse University News, published online 4 August 2014. < http://news.syr.edu/students-meld-creativitycommunity-needs-in-field-house-redesign-11565/> 